DOI: $10.14720 /$ aas.2016.107.2.17

Agrovoc descriptors: wines, phenolic compounds, phenols, volatile compounds, winemaking, wine yeast, aromatic compounds, flavour compounds, production technology

Agris category code: Q01, Q02, Q04

\title{
Volatile phenols in wine: Control measures of Brettanomyces/Dekkera yeasts
}

\author{
Sanja ŠUĆUR ${ }^{1}$, Neža ČADEŽ², Tatjana KOŠMERL ${ }^{3}$
}

Received July 29, 2016; accepted September 28, 2016.

Delo je prispelo 29. julija 2016, sprejeto 28. septembra 2016.

\begin{abstract}
This review focuses on the considerable amount of research regarding volatile phenols production by Brettanomyces and on microbiological and technological parameters that influence development of these compounds during all stages of grape processing and winemaking. Also, volatile phenols impact on wine aroma and quality and prevention methods were discussed. The yeast genus Brettanomyces is the major microorganism that has the ability to convert hydroxycinnamic acids into significant concentration of phenolic compounds, especially of 4-ethylphenol and 4-ethylguaiacol, in red wine. When volatile phenols reach concentrations above the sensory threshold in wine, it is then characterized as wine with fault. In order to control the growth of Brettanomyces and preclude volatile phenols production, it is helpful to keep good quality of grape, winery sanitation, control of oxygen and sulphite level, as well as orderly check physiochemical composition of wine.
\end{abstract}

Key words: wine, volatile phenols, Brettanomyces, growth, factors, prevention

\section{IZVLEČEK}

\section{HLAPNI FENOLI V VINU: KONTROLNI UKREPI ZA KVASOVKE Brettanomyces/Dekkera}

Ta pregled se osredotoča na znatno število raziskav, ki preučujejo tvorbo hlapnih fenolov $\mathrm{s}$ kvasovkami rodu Brettanomyces, ter na mikrobiološke in tehnološke parametre, ki vplivajo na sintezo tovrstnih fenolov v vseh fazah predelave grozdja in predelave vina. Prav tako je obravnavan tudi vpliv hlapnih fenolov na aromo in kakovosti vina ter preventivni ukrepi. Kvasovke rodu Brettanomyces so glavni mikroorganizmi, ki imajo sposobnost pretvorbe hidroksicimetnih kislin $\mathrm{v}$ značilne vsebnosti prisotnih hlapnih fenolov $v$ rdečem vinu, predvsem 4-etilfenola in 4etilgvajakola. Ko hlapni fenoli dosežejo koncentracije nad senzoričnim pragom zaznave za vino, je potem le-to spoznano kot vino $\mathrm{z}$ napako. $\mathrm{Za}$ nadzor rasti kvasovk rodu Brettanomyces in preprečevanje nastajanja hlapnih fenolov je koristno upoštevati kontrolo kakovosti grozdja ob trgatvi, higienske razmere $\mathrm{v}$ vinski kleti, kontrolo količine kisika in sulfita, ter redno kontrolo fizikalno-kemijske sestave vina.

Ključne besede: vino, hlapni fenoli, Brettanomyces, rast, dejavniki, preprečevanje

\section{INTRODUCTION}

Wine is a complex mixture of hundreds of compounds and most of them contribute to sensory characteristics of wine such as the colour, mouthfeel and aroma. There is a huge interest in wine aroma and numerous components are identified as playing a role in specific sensory notes. Flavour and aroma of wine are determined by many factors including grapevine variety, viticultural and winemaking practices, wine maturation and aging conditions. Besides, a wide range of microorganisms influence wine aroma. These microorganisms come into contact with wine

\footnotetext{
1 ”13. Jul Plantaže", Sector for Development, Put Radomira Ivanovića 2, 81000 Podgorica, Montenegro, email: sucursanja@yahoo.com

2 Doc., Ph.D., University of Ljubljana, Biotechnical faculty, Department of Food Science and Technology, University of Ljubljana, Jamnikarjeva 101, 1000, Ljubljana, Slovenia

3 Prof., Ph.D., University of Ljubljana, Biotechnical faculty, Department of Food Science and Technology, University of Ljubljana, Jamnikarjeva 101, 1000, Ljubljana, Slovenia
} 
during grape processing and wine production and their metabolic activities, synthetic and degrading enzymes impact wine aroma. Volatile phenols are important group of compounds that can be formed in wine and their elevated concentrations are associated with unpleasant smelling aroma often described as "phenolic", "leather", "horse sweat", "stable" or "varnish", etc. (Chatonnet et al., 1993; Chatonnet et al., 1992; Rodrigues et al., 2001). Within this group of compounds the most widely represented are 4-vinylphenol, 4-vinylguaiacol, 4ethylphenol and 4-ethylguaiacol. The most unpleasant odoured are 4-vinylphenol (reminiscent of pharmaceuticals, gouache paint and 'Band Aids') and 4-ethylphenol (stables and sweaty saddles). Also, 4-vinylguaiacol (carnations) and 4vinylguaiacol, (smoky, spicy aromas) are much less unpleasant, but however they are always associated with 4-vinylphenol and 4-ethylphenol, respectively. The olfactory impact of the two vinylphenols or ethyl-phenols should therefore be considered together, in the proportions in which they are present in the wine (Ribéreau-Gayon et al., 2000).

The origin of ethylphenols in wine aroma is due to different sources, but the most usual ways of formation are enzymatic processes of wine yeast and aging. Volatile phenols formation involves the sequential action of two enzymes on a hydroxycinnamic acid (ferulic, p-coumaric or caffeic acid) substrate. Hydroxycinnamate decarboxylase first turns these hydroxycinnamic acids into hydroxystyrenes (vinylphenols), which are then reduced to ethyl derivatives by vinylphenol reductase (Edlin et al., 1998; Dias et al., 2003). The enzyme that facilitates decarboxylation is present in a large number of bacteria, fungi, and yeasts, but it is shown that the reduction step is only performed by the species Brettanomyces bruxellensis Kufferath \& von Laer
(Dekkera bruxellensis van der Walt), Dekkera anomala Smith et van Grinsven, Pichia guillermondii Wickerham, Candida versatilis (Etchells \& T.A. Bell) S.A. Mey. \& Yarrow, Candida halophila Yarrow \& S.A. Mey and Candida mannitofaciens (Onishi \& Tom. Suzuki) S.A. Mey. \& Yarrow (Chatonnet et al., 1995; Edlin et al., 1995; Chatonnet et al., 1997; Dias et al., 2003). Lactic acid bacteria may produce significate amounts of vinylphenols but produce only traces of ethylphenols under wine conditions (Chatonnet et al., 1995, 1997). The fermenting yeast Saccharomyces cerevisiae Meyen ex E.C. Hansen and other wine contaminants (e.g. Pichia sp., Torulaspora sp., Zygosaccharomyces sp.), may also produce 4-vinylphenol but are incapable of producing 4-ethylphenol (Chatonnet et al., 1993, 1995; Rodrigues et al., 2001). In D. bruxellensis the enzymes cinnamate decarboxylase and vinylphenol reductase are active under wine conditions and so these yeasts should be regarded as the off-flavour producers (Chatonnet et al., 1995, 1997). It is turned out that, 4-ethylguaiacol and 4-ethylphenol are formed in very small concentrations during malolactic fermentation by Lactobacillus able to transform phenolic acids in ethyl phenols (Baumes et al., 1986; Dubois, 1983). It has also been observed that ethyl phenols increase in wine during the aging and high levels were found in wine aged in used barrels (Chatonnet et al., 1992).

In this review we examine important group of compounds that influence wine aroma - volatile phenols, their origin in wine, emphasizing parameters that influence growth and activities of Brettanomyces/Dekkera yeast, as well as, the measures of prevention its development and volatile phenols production.

\section{VOLATILE PHENOLS IN WINE}

The accumulation of volatile phenols in wine has been a cause of great concern in modern oenology being now a key point in the control of wine quality. The quality of wine is considered to be mainly affected by the accumulation of 4ethylphenol and 4-ethylguaiacol, whose presence is commonly described as responsible for sensorial notes reminiscence of leather, horse sweat, animal, and medicinal. Actually there are six compounds responsible for the phenolic flavour: 4ethylguaiacol, 4-ethylphenol, 4-ethylcatechol and their precursors 4-vinylguiacol, 4-vinylphenol and 4-vinylcatechol (Fig. 1).Volatile phenols found in wines are microbial derived product formed from 
hydroxynnamic acids naturally present in grapes (Boulton et al., 1996). Vinylphenols (4vinylphenol and 4-vinylguaiacol) and ethylphenols (4-ethylphenol and 4-ehtylguaiacol) may be produced in wine, in a sequential pathway, due to microbial activity, imparting undesirable odours and flavours. Mainly, they are formed by metabolism of hydroxycinnamic acid (ferulic, $p$ coumaric or caffeic acid) substrate by Brettanomyces/Dekkera yeast which involves the sequential action of two enzymes. Hydroxycinnamate decarboxylase first turns these hydroxycinnamic acids into hydroxystyrenes (vinylphenols), which are then reduced to ethyl derivatives by vinylphenol reductase (Figure 1). The decarboxylation step is present in a large number of bacteria, fungi and yeast species (Degrassi et al., 1995; Edlin et al., 1995; Suezawa et al., 1995). The reduction step is much less frequent and has been reported as particularly effective in the species Dekkera bruxellensis (Chatonnet et al., 1995, 1997), D. anomala (Edlin et al., 1995), Pichia guilliermondii (Dias et al., 2003), Candida versatilis, C. halophila and $C$. mannitofaciens (Suezawa, 1995).

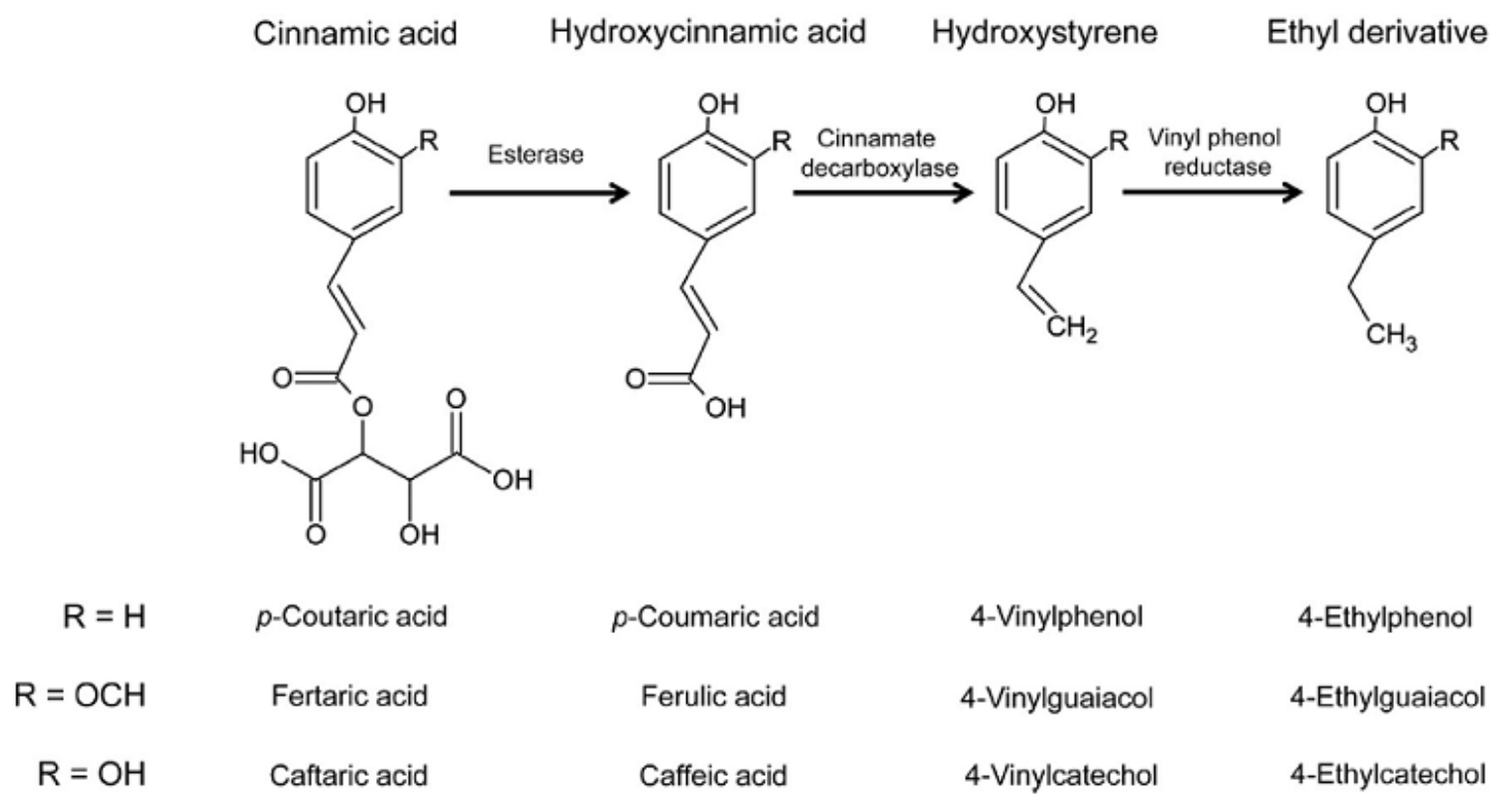

Figure 1: The formation of volatile phenols from their hydroxycinnamic acids precursors

Slika 1: Tvorba hlapnih fenolov iz prekurzorjev hidroksicimetnih kislin

The presence of this kind of aroma character can be considered either negative or positive depending on the concentration and expectation of a particular wine. At low concentration, these compounds can contribute to aroma complexity, but in concentration above threshold can create an unpleasant experiences (Chatonnet et al., 1990). Also, the judgment of brett wines is controversial and depends on individual and cultural preferences (Wedral et al., 2010).

Based on the literature, there are a lot of reports on presence of Brettanomyces metabolites in wine indicating a worldwide issue. Although only trace amounts are present in must, wine contains volatile phenols at concentrations between a few tens and several hundreds of $\mu \mathrm{g} \mathrm{I}^{-1}$ (Dubois, 1983; Chatonnet et al., 1988). The perception threshold of an odoriferous compound is conventionally considered to be the minimum concentration at which its presence in a model dilute alcohol solution is detectable by $50 \%$ of trained tasters. The recognition threshold of an odoriferous compound corresponds to its perception threshold in wine. The preference threshold of a compound is the concentration above which the overall aroma of a wine is affected. In the case of vinyl- and ethylphenols, the preference thresholds have been estimated at $720 \mu \mathrm{g} \mathrm{l}^{-1}$ for 4-vinylphenol and 4vinylguaiacol in white wines, and at $420 \mu \mathrm{g} 1^{-1}$ for 4-ethylphenol and 4-ethylguaiacol in red wines. It has been reported (Licker et al., 1999) that wines 
with high, medium and no brett character have an average 4-ethylphenol concentrations of 3.00, 1.74 and $0.68 \mathrm{mg} \mathrm{l}^{-1}$, respectively.

Volatile phenols concentration in red wine and its sensory descriptors are presented in Table 1 (Steensels et al., 2015; Curtin et al., 2005). White wines contain variable quantities of vinyl-phenols but comparing to red wines almost no of ethylphenols. On the contrary, reds contain only small quantities of vinyl-phenols and have variable concentrations of ethyl-phenols (Table 2). The volatile phenol composition of rose wines is between those of red and white wines (Chatonnet et al., 1992b, 1993b). The variety of grapevine used also affects the sensorial perception of ethylphenols. Phister and Mills (2004) indicated the detection thresholds to be high in monovarietal Cabernet Sauvignon wines, and lower in Tempranillo wines. Pollnitz et al. (2000) analysed 61 bottles of different commercially available varietal Australian red wine, where a 4-ethylphenol was detected in all analysed wines. The concentrations found in the wines varied between $2 \mu \mathrm{g}^{-1}$ in a Merlot and $2660 \mu \mathrm{g}^{-1}$ in a Shiraz, with a mean concentration of $795 \mu \mathrm{g} \mathrm{l}^{-1}$. 4Ethylguaiacol was also found in every red wine analysed, varying in concentration from $1 \mu \mathrm{g} \mathrm{l^{-1 }}$ in a Pinot Noir up to $437 \mu \mathrm{g} \mathrm{L}^{-1}$ in a Merlot with a mean concentration of $99 \mu \mathrm{g}^{-1}$. An average ratio of 4-ethylphenol and 4-ethylguaiacol was approximately 10:1 for Cabernet Sauvignon, 9:1 for Shiraz, 8:1 for Merlot and 3.5:1 for Pinot Noir, what is in accordance with reports by Chatonnet et al. (1992; 1995).

The ratio of 4-ethylphenol to 4-ethylguaiacol also varied from wine to wine with reports varying from 3:1 to over 40:1 (Gawel et al., 2004; Steensels et al., 2015). The reason for these differences in wine are still not fully understood, even though they are likely caused by the combined effect of differing ratios between wines $p$-coumaric and ferulic acids (the precursors of 4ethylphenol and 4- ethylguaiacol, resp.) and of different strains of Brettanomyces/Dekkera with some being more effective in producing one compound relative to the other (Buron et al., 2012; Gawel, 2004; Vigentini et al., 2008). Fariña et al. (2007) analysed six Tannat wines from Uruguay and results indicated that in three of the six analysed wines the 4-ethylphenol was found, and quantified in two of them with concentrations of 1120 and $170 \mathrm{~g} \mathrm{l}^{-1}$. 4-ethylguaiacol was quantified only in one of the six wine samples, in concentrations of $120 \mathrm{~g} \mathrm{l}^{-1}$. Recently Baša-Česnik et al. (2016) determined 4-ethylphenol, 4vinylphenol, 4- ethylguaiacol and 4-vinylguaiacol in Teran PTP wines that were produced in the Kras winegrowing district (Slovenia). During the 20112013 periods, these authors found average concentrations: $153 \pm 193 \mu \mathrm{g} \mathrm{l^{-1 }}$ for 4-ethylphenol, $1265 \pm 682 \mu \mathrm{g} \mathrm{l^{-1 }}$ for 4-vinylphenol, $69 \pm 94 \mu \mathrm{g} \mathrm{l^{-1 }}$ for 4-ethylguaiacol and $128 \pm 106 \mu \mathrm{g} \quad \mathrm{l}^{-1}$ for 4vinylguaiacol. Earlier from the same region the concentration of 4-ethylphenol in bottle-aged Teran PTP wines was reported to be 1016, 678 and $616 \mu \mathrm{g} \mathrm{l}^{-1}$ for the 2007, 2008 and 2009 vintages, respectively (Čuš et al., 2011).

Volatile phenols are usually analysed by gas chromatography, after their extraction from the sample. Traditionally, liquid-liquid extraction methods were employed (Monje et al., 2002; Chatonnet, 1988), but now simpler and more selective extraction methods are applied, such as solid-phase extraction (SPE) (López et al., 2002; Domínguez et al., 2002) solid-phase microextraction (SPME) (Monje et al., 2002; Martorell et al., 2002) or stir bar sorptive extraction (SBSA) (Díez et al., 2004). 
Table 1: Volatile phenols in wine (Steensels et al., 2015; Curtin et al., 2005)

Preglednica 1: Hlapni fenoloi v vinu (Steensels in sod., 2015; Curtin in sod., 2005)

\begin{tabular}{|lll|}
\hline & Concentration in red wine $(\mathrm{ppb})$ & Sensory descriptor \\
\hline 4-vinylphenol & $8.8-43$ & Phenolic, medicinal \\
4-vinylguaiacol & $0.2-15$ & Clove-like \\
4-ethylphenol & $118-3696$ & Medicinal, horsy \\
4-ethylguaiacol & $1-432$ & Spicy, clove-like \\
4-ethylcatechol & $27-427$ & Phenolic, medicinal \\
\hline
\end{tabular}

Table 2: Ethyl- and vinyl-phenol concentrations in different wines $\left(\mu \mathrm{g} \mathrm{l}^{-1}\right)$ (Chatonnet et al., 1992, 1993)

Preglednica 2: Vsebnosti etil- in vinilfenolov v različnih vinih $\left(\mu \mathrm{g} \mathrm{l}^{-1}\right)$ (Chatonnet in sod., 1992, 1993)

\begin{tabular}{|c|c|c|c|}
\hline Volatile phenols & $\begin{array}{c}\text { White wines } \\
n=54\end{array}$ & $\begin{array}{c}\text { Rose wines } \\
n=12\end{array}$ & $\begin{array}{c}\text { Red wines } \\
n=83\end{array}$ \\
\hline \multicolumn{4}{|l|}{ Vinyl-4-phenol } \\
\hline Minimum & 73 & 3 & 0 \\
\hline Maximum & 1150 & 215 & 111 \\
\hline Mean & 301 & 71 & 35 \\
\hline Standard deviation (\%) & 79 & 99 & 75 \\
\hline \multicolumn{4}{|l|}{ Vinyl-4-guaiacol } \\
\hline Minimum & 15 & 4 & 0 \\
\hline Maximum & 496 & 75 & 57 \\
\hline Mean & 212 & 17.5 & 12 \\
\hline Standard deviation (\%) & 44 & 113 & 79 \\
\hline \multicolumn{4}{|l|}{ Ethyl-4-phenol } \\
\hline Minimum & 0 & 0 & 1 \\
\hline Maximum & 28 & 75 & 6047 \\
\hline Mean & 3 & 20 & 440 \\
\hline Standard deviation (\%) & 229 & 122 & 179 \\
\hline \multicolumn{4}{|l|}{ Ethyl-4-guaiacol } \\
\hline Minimum & 0 & 0 & 0 \\
\hline Maximum & 7 & 15 & 1561 \\
\hline Mean & 0.8 & 3 & 82 \\
\hline Standard deviation (\%) & 225 & 159 & 230 \\
\hline
\end{tabular}

Coulter et al. (2004) concluded that the extent to which the sensory properties of a wine may be affected by 4-ethylphenol depends on the style and structure of the wine, i.e. the concentration and intensity of other wine compounds that could mask (e.g. volatile oak compounds) or accentuate (e.g. 4ethylguaiacol) the aroma of 4-ethylphenol. For example, in a light-bodied red wine with little oak influence, the sensory perception threshold of 4ethylphenol may be as low as concentration of 350 $\mu \mathrm{g} \mathrm{1^{-1 }}$, compared with $1000 \mu \mathrm{g} \mathrm{l^{-1 }}$ in a full-bodied red wine with intense fruit and considerable oak influence. 


\section{THE PRODUCTION OF VOLATILE PHENOLS BY BRETTANOMYCES/DEKKERA}

Brettanomyces bruxellensis is yeast found on surfaces of grapes as well as in barrels, but the greatest concern is its presence in wine. The yeasts of the genus Brettanomyces, or its teleomorph Dekkera, were first described by Claussen in 1903, in beer production (Gilliland, 1961). Brettanomyces/Dekkera yeasts exist in two forms: Brettanomyces, the asexual, non-sporulating form, and Dekkera, the sexual, sporulating form. These genera are particularly known as spoiling agents in beer, wine, cider and soft drinks industries (Deak and Beuchat, 1996). The current taxonomy includes five species within the genera of Dekkera/Brettanomyces. Those are the anamorphs Brettanomyces bruxellensis, Brettanomyces anomalus Custers, Brettanomyces custersianusvan der Walt, Brettanomyces naardenensis Kolfsch. \& Yarrow, and Brettanomyces nanus (M.T. Sm., Bat. Vegte \& Scheffers) M.T. Sm., Boekhout, Kurtzman \& O'Donnell, with teleomorphs existing for the first two species, Dekkera bruxellensis and Dekkera anomala (Cocolin et al. 2004; Oelofse et al., 2008). Different strains of Brettanomyces can show great differences in their production of volatile phenols (Joseph and Bisson, 2004). In wines, the metabolic products responsible for spoilage by Brettanomyces/Dekkera sp. are mainly volatile phenols, isovaleric (3-methylbutyric) acid, tetrahydropyridines and acetic acid (Heresztyn, 1986; Licker et al., 1999; Larue et al., 1991; Ciani and Ferraro, 1997). Coulter et al. (2004) found that 4-ethylphenol and 4-ethylguaiacol (both compounds associated with 'Band-aid', 'medicinal', 'barnyard' and 'stable' aroma characters and 'metallic' taste attributes) were the main compounds derived from Brettanomyces that were associated with off-odours in red wines. They found that the concentration of isovaleric acid (associated with 'sweaty', 'cheesy' and 'rancid' characters) was independent of the concentrations of these two key spoiler compounds. It therefore appears that isovaleric acid may be involved in additional sensory effects with other Brettanomyces-derived compounds, thereby enhancing the apparent aroma intensity of those other compounds.

Works on D. bruxellensis have mainly focused on its early detection to reduce economic losses
(Wedral et al., 2010). Also, studies have been carried out to understand the mechanisms of 4vinylphenol and 4-ethylphenol production (Dias et al., 2003; Godoy et al., 2008; Harris et al., 2008; Harris et al., 2009). Barata et al. (2008) concluded that the production of 4-ethylphenol in red wines is related to the presence of growing populations of D. bruxellensis, demonstrating that the primary management objective should not be their complete elimination but their maintenance at constant levels. If the numbers of $D$. bruxellensis increase, removal or inactivation procedures must be performed. Coulon et al. (2009) highlighted a relationship between the physiological state of $B$. bruxellensis, and its capacity to produce volatile phenols. Cultivable populations seem indeed able to synthesize higher amounts of ethyl-phenols than viable but non-cultivable cells. They also stated that sequential ethyl-phenol production could systematically be correlated to the B. bruxellensis physiological state and found that maximum vinylphenol concentrations were found with fastmultiplying cells. They then decreased, indicating that the yeast metabolism is centred on ethylphenol production. This was generally accompanied by a population regression or/and a non-cultivable state shift. Other authors had already noted that ethyl-phenols synthesis occurred during the late exponential phase or stationary growth phase in synthetic media (Dias et al. 2003; Harris et al. 2008) or wine (Romano et al. 2008). This indicates that the overall information about the growth physiology of $D$. bruxellensis and metabolite production appears to be sometimes contradictory. Some authors concluded that production of ethylphenols was intrinsically related to D. bruxellensis growth (Barata et al., 2008b; Dias et al., 2003; Vigentini et al., 2008), whereas other studies suggest the existence of a sulphiteinduced viable but non-culturable subpopulation, which is able to produce vinylphenols and ethylphenols (Agnolucci et al., 2010; Laforgue and Lonvaud-Funel, 2012; Serpaggi et al., 2012).

Brettanomyces spoilage of wine usually occurs when they are fermented or aged in oak barrels (Rayne et al., 2008). The yeast grows slowly so it usually imparts flavours only when the wine is aged. Since Brettanomyces is present at low 
numbers early in the fermentation, it is outnumbered by other indigenous yeast and may go undetected (Wedral et al., 2010). Garde-Cerdán et al. (2002) investigated the behaviour of the barrels at the completion of their cycle of use (5-6 years old) on the volatile composition of a red wine. In all the wines high concentrations of 4ethylphenol and 4-ethylguaiacol were found, and these have a negative impact on the quality of the product, probably due to the presence of contaminating microflora as the barrels were old (Garde-Cerdán et al., 2002).

The results of Silva et al. (2011) suggest that the conversion of $4 \mathrm{VP}$ into $4 \mathrm{EP}$, catalysed by the vinylphenol reductase, may lead to the re-oxidation of NADH. An analogous statement was made by Fugelsang and Edwards (2007) for Brettanomyces/Dekkera: since a reduced cofactor is generally required for the enzymatic reduction activity, it is likely that the production of volatile phenols, specifically the reduction of 4vinylphenol into 4-ethylphenol, is a source of $\mathrm{NAD}^{+}$during growth of this organism by maintaining the redox balance of its cells in red wines.

However, red wines are more susceptible to Brettanomyces bruxellensis due to their lower acidity, higher polyphenol concentration and barrel aging. Therefore Vitis vinifera red varieties with higher polyphenol concentration are the most susceptible to the Brett (Wedral et al., 2010). The loss of viability in white wines is largely due to the efficacy of sulphur dioxide at low $\mathrm{pH}$ (Loureiro et al., 2006) and due to absence of precursor compounds (Chatonnet et al., 1992).

\subsection{Factors affecting growth of Brettanomyces and production of volatile phenols}

\subsubsection{Carbon and energy sources}

Bioconversion of ethylphenols precursors, like $p$ coumaric, by $B$. bruxellensis is highly dependent on the growth media (Dias et al., 2003) and cinnamic acid ratios (Romano et al., 2008). Dias et al. (2003) showed that reduction step was dependent on the carbon and energy source, i.e. high conversion rates of $p$-coumaric acid to 4ethylphenol only occurred when glucose or ethanol were substrate. Regarding to trehalose sugar, Chatonnet et al. (1995) suggested that this residual sugar may allow synthesis of 4-ethylphenol. These results are not in agreement with Dias et al. (2003) who demonstrated that contribution of this sugar to the overall production of 4-EP is not relevant in wine.

D. bruxellensis grown in the presence of glucose showed relatively low growth rate compared to other wine related yeast such as S. cerevisiae and Z. bailii (Lindner) Barnet et al. (Rodrigues et al., 2001a). Vigentini et al. (2008) found that $D$. bruxellensis used fructose as a preferred carbon source in a synthetic medium with a high concentration of ethanol. Also, the amount of less than $2 \mathrm{~g} \mathrm{l}^{-1}$ fermentable sugar in "dry" wines is still not limitation to the production of 4-EP by $D$. bruxellensis. The production of 4-ethylphenol was detected at sugar concentrations over $0.2 \mathrm{~g} \mathrm{l}^{-1}$ and increased under higher sugar concentrations (Barata et al., 2008). In line with this, Sturm et al. (2015) showed that $210 \mathrm{mg} \mathrm{l}^{-1}$ of sugars (glucose, fructose and trehalose) was enough to allow $B$. bruxellensis growth. Sugars were completely consumed during the first growth phase, whilst consumption of glucose and fructose was faster than trehalose.

The growth of Brettanomyces/Dekkera in synthetic media containing autolysed Saccharomyces cerevisiae has also been studied (GuillouxBenatier et al., 2001). Under these conditions it was observed that these contaminating yeasts grew easily, even in glucose concentrations of less than $150 \mathrm{mg} \mathrm{l}^{-1}$. However the quantity of ethylphenols formed was smaller than expected, probably because of the adsorption of the phenolic compounds by the cell wall fragments. More recent studies have reported the high capacity of yeast cell walls to adsorb phenolic compounds (Morata et al., 2005; Morata et al., 2003).

The inhibition of growth and 4-ethylphenol production by $13 \%(\mathrm{v} / \mathrm{v})$ of ethanol is observed in wines with high concentration of ethanol and these wines did not show high concentrations of this phenol (Rodrigues et al., 2001; Dias et al., 2003). These authors showed that 4-ethylphenol concentrations in wines were not correlated with acetic acid concentrations expect in media with high sugar concentration, as also observed by Gerós et al. (2000) in D. anomala. This observation indicates that these two $D$. bruxellensis 
spoiling features (acetic acid and 4-ethylphenol production) are independent. However, acetic acid production is variable among strains of the genera Dekkera/Brettanomyces cultivated under the same conditions (Freer, 2002).

Barata et al. (2008) demonstrated that even in the presence of a carbon and energy source, the levels of volatile phenols do not increase in commercial red wines when $D$. bruxellensis is not growing. This conclusion has direct implications in the management of the phenolic taint, because it shows that the primary objective should be the prevention of actively growing populations and not the reduction of $D$. bruxellensis to the lowest possible level, as suggested by Renouf et al. (2007). In fact, complete absence of viable cells of $D$. bruxellensis is not easy to achieve under winery conditions, especially when oak aging is used due to the porous nature of the wood (as discussed by Loureiro and Malfeito-Ferreira, 2006).

Coulon et al. (2009) confirmed as it has previously been observed that $B$. bruxellensis is not very demanding from a nutritional point of view and that it can grow with other energy sources than glucose and fructose (Alguilar Uscanga et al., 2000; Conterno et al., 2006).

\subsubsection{Precursors}

The biosynthesis of volatile phenols is related to the sequential activity of two enzymes which decarboxylate hydroxycinnamic acids (ferulic, $p$ coumaric and caffeic acids) spontaneously present in grapes into vinylphenols, which are then reduced to ethylphenols (Steinke et al., 1964). The formation of volatile phenols in wine depends on the presence of precursors and is proportional to the size of the Brettanomyces/Dekkera population (Gerbeaux et al., 2000, Suárez et al., 2007). It has previously been suggested that microorganism's decarboxylate HCAs in order to produce less toxic compounds (Goody et al., 1982). Vinyl-phenol reductase and cinnamate decarboxylase, the two enzymes involved in ethyl-phenol production in $B$. bruxellensis are precursor inducible, but these precursors also have an inhibitory effect on $B$. bruxellensis growth (Harris et al., 2008). Variations in wines can be noted because of the instability, esterification and cell-adsorption of $p$ coumaric acid (Salameh et al., 2007).
Grapevine varieties differ in the quantity of phenolic acids present in the berries (Rodrigues et al., 2001; Morel-Salmi et al., 2006; Morata et al., 2007; Rentzsch et al., 2007). The presence of the three hydroxycinnamic acids (caffeic acid, ferulic acid and $p$-coumaric acid) in grapes originate from their bound form with tartaric acid known as caftaric acid, fertaric acid and coutaric acid, respectively. Goldberg et al. (1998) measured the concentration of $p$-coumaric acid, the precursor to 4-ethylphenol, in single variety red wines from various countries and found that Pinot Noir had a lowest concentration of $p$-coumaric acid, among all studied varieties and countries. General concentrations for hydroxycinnamic acids present in Vitis vinifera L. juice (oxidative and hydrolytic losses prevented) are about $150 \mathrm{mg} \mathrm{l}^{-1}$ of caftaric acid, $20 \mathrm{mg} \mathrm{l}^{-1}$ of coutaric acid and $1.0 \mathrm{mg} \mathrm{l}^{-1}$ of fertaric acid (Boulton et al., 1996). Other grapevine varieties have been identified to have higher amounts of hydroxycinnamic acids for example wines from Grenache variety can contain between 270-460 $\mathrm{mg} \mathrm{l}^{-1}$ of caftaric acid (Morel-Salmi et al., 2006). Other wine varieties mean values for caftaric acid range from 50 to $60 \mathrm{mg} \mathrm{l}^{-1}$ (Rentzsch et al., 2007). Dias et al. (2003) studied the capacity of a number of yeasts present in wine microbiota to produce 4-ethylphenol from $p$-coumaric in model media. Molar conversions of $90 \%$ were reported for $D$. bruxellensis, $D$. anomala and $P$. guillermondii; other fermentative yeasts were incapable of producing 4-ethylphenol at these rates of conversion.

Recently, Cabrita et al. (2012) showed that phenolic acids concentration decreases while volatile phenols concentration increases and the proportion of caffeic acid taken up by Dekkera bruxellensis is lower than that for $p$-coumaric or ferulic acid, i.e. less 4-ethylcatechol is formed. Before, the presence of 4-ethylcatechol, has been reported only once, by Hesford et al. (2004), until Carrillo and Tena (2007) reported the presence of 4-ethylcatechol in some wines affected by Brettanomyces. Study of Cabrita et al. (2011) has shown that 4-ethylcatechol is the last one to appear in wine, and it is the least significant. In this study conversion rates greater than $90 \%$ were obtained for the conversion of $p$-coumaric acid into 4ethylphenol and from ferulic acid into 4ethylguaiacol, but a rate smaller than $20 \%$ was 
ethylcathecol. These results may justify why only the presence of 4-ethylcatechol in wines was reported (Hesford et al., 2004). Although caffeic acid is present in wines in considerable amounts and has a structure similar to the other phenolic acids, these results seem to indicate that $p$ coumaric and ferulic acids are easily used by yeast metabolism.

In the study of Sturm et al. (2015), all five examined $D$. bruxellensis strains were able to simultaneously metabolise $p$-coumaric and ferulic acid with production of their respective volatile phenols, being the conversion rate of ferulic acid lower than $p$-coumaric acid. In contrast, Oelofse et al. (2009) suggested that the conversion pathway of ferulic acid as precursor was preferred to $p$ coumaric acid by different $D$. bruxellensis strains grown in wine spiked with similar amounts of both compounds $\left(100 \mathrm{mg} \mathrm{l}^{-1}\right)$. Besides, the ratio of $p$ coumaric and ferulic acid was 8:1 (Sturm et al., 2015) and it has been proven that ferulic acid is slightly more toxic to the yeast than $p$-coumaric acid (Harris et al., 2008).

Recently, Lentz et al. (2015) showed that caffeic acid was the weakest inhibitor of the HCAs tested. This observation is in general agreement with published data for other strains that show weak or no inhibition of growth by this compound compared to other cinnamic acids (Harris et al., 2009). When a strain showed variation for inhibition by ferulic acid and $p$-coumaric acid, it's turned out that ferulic acid was always a more potent inhibitor (Lentz et al., 2015). This data supports results from similar experiments using different strains of $B$. bruxellensis and $B$. anomalus (Harris et al., 2009). It appears that Brettanomyces in general are only weakly inhibited by caffeic acid, and are slightly more susceptible to ferulic than $p$-coumaric acid.

Kosel et al. (2014) examined the impact of ethanol, and hidroxycinnamic and vinylphenol precursors on the production of volatile phenols in fermentations of mixed and pure cultures of yeasts Saccharomyces cerevisiae and Dekkera bruxellensis. Results showed that in mixed culture fermentations less vinylphenols and more ethylphenols were produced in comparison with $D$. bruxellensis pure culture fermentations. Vinylphenol precursors significantly inhibited the growth of $S$. cerevisiae and the production of ethylphenols. It was found that $D$. bruxellensis genes encoding for enzymes coumaric acid decarboxylase (CAD) and vinylphenol reductase (VPR) are more responsive to vinylphenol precursors in comparison with hidroxycinnamic acids. Consequently, higher concentrations of vinylphenols in the cell were found to be more cytotoxic than hidroxycinnamic acids. Also, these authors showed that $10 \%$ of ethanol strongly reduced the growth and volatile phenol production of yeasts $D$. bruxellensis and $S$. cerevisiae.

\subsubsection{Temperature, ethanol concentration, $\mathrm{pH}$}

The impact of different chemical factors and different temperatures on volatile phenol production has been well studied. Different strains of $B$. bruxellensis vary in their capacity to produce volatile phenols and it is always greater at lower alcohol concentrations (more are made at $12 \% \mathrm{v} / \mathrm{v}$ than at $14 \% \mathrm{v} / \mathrm{v}$ ) and at higher temperatures (e.g., more is produced at $18{ }^{\circ} \mathrm{C}$ than at $13{ }^{\circ} \mathrm{C}$ ) (Gerbeaux et al., 2000). Recently, study of Kosel et al. (2014) confirmed that low ethanol concentrations induced higher production of volatile phenols by $S$. cerevisiae and $D$. bruxellensis. Little significance is attributed to the $\mathrm{pH}$ of the wine or the presence of residual sugars in this respect. The intensity and temperature of maceration and the use of pectolytic enzymes have been studied as possible factors conditioning the formation of volatile phenols by Brettanomyces and Dekkera from hydroxycinnamic acids released from the grape skins (Gerbeaux et al., 2002). Godoy et al. (2008) demonstrated that both enzymatic activities were stable at $\mathrm{pH} 3.4$, but in the presence of ethanol the coumarate decarboxylase activity decreased drastically while the vinyl reductase activity was more stable.

Dias et al. (2003) described that a $5 \%$ ethanol concentration is adequate to obtain volatile phenols in the culture medium, since an increase in ethanol concentration is detrimental to the yeast population and consequently leads to a decrease in volatile phenols. Garde-Cerdán et al. (2008) showed that alcohol concentration was the oenological parameter that had the greatest impact on the accumulation of volatile compounds in wines and according to same author accumulation of ethylphenols in the wines diminished as the 
alcohol concentration of the wines increased from $12.5 \%$ to $13.5 \%$.

Results obtained by Ganga et al. (2011) are similar to that obtained by Dias et al. (2003) and GardeCerdán et al. (2008), where although D. bruxellensis presents basal coumarate decarboxylase activity, it is necessary to add ethanol to the culture medium to increase its production. Ganga et al. (2011) investigated the influence of the interaction between the concentration of $p$-coumaric acid, ferulic acid and ethanol as well as growth temperature on the production of $\mathrm{CD}$ activity and the expression of a putative gene that codes for this enzymatic activity. These authors concluded that the interaction of cinnamic acids with growth temperature, and growth temperature with ethanol concentration, as well as ethanol concentration, are highly important variables in the production of $\mathrm{CD}$ activity. Analysing the assayed growth temperatures $\left(16^{\circ} \mathrm{C}\right.$ to $28^{\circ} \mathrm{C}$ ) shows that the increase of this parameter brings about a decrease of coumarate decarboxylase activity. This affirmation is not in accordance with reports by Benito et al. (2009), who indicated that at a temperature between 20 and $30{ }^{\circ} \mathrm{C}$ the yeast consumes the greatest quantity of $p$-coumaric acid, which is indirectly associated to the presence of higher coumarate decarboxylase activity. At $22{ }^{\circ} \mathrm{C}$ with 10 vol. $\%$ alcohol, the yeast on average only metabolizes $38 \%$ of the $p$ coumaric acid in the culture medium, while with $3 \%$ ethanol, $74 \%$ of the initial $p$-coumaric acid was metabolized by the yeast. This result was also obtained at $16{ }^{\circ} \mathrm{C}$. Salameh et al. (2008) indicated that $p$-coumaric acid can react with the ethanol in the medium or be absorbed through the yeast wall, which leads to a decrease in the acid concentration in the culture medium. A slow metabolization of $p$ coumaric acid in the culture medium is closely related to the growth rate of the yeast, with yeast growth slower at $10 \%$ than at $3 \%$.

\subsubsection{Conditions during aging and storage of wine}

The use of old wooden casks can increase the presence of Brettanomyces and Dekkera species in wine due to difficult cleaning and impossibility of their sterilization. Brettanomyces/Dekkera has been found at $8 \mathrm{~mm}$ down within the wood of barrel staves (Malfeito-Ferreira, 2006). These yeasts survive treatments where contact with $\mathrm{SO}_{2}$ is limited, e.g., around bung holes, in the oak structure, and in yeast sediments (lees). Besides, Brettanomyces custersii and Dekkera intermedia metabolise cellobiose, a disaccharide, forming the basic repeating unit of cellulose (a structural polysaccharide of wood) (Freer, 1991; Park et al., 1999; Park et al., 2000).

The age of the barrel greatly influences the growth of Brettanomyces populations during the long aging of red wines. Old barrels favour Brettanomyces contamination - oak wood is extremely porous and yeasts deep in the barrel staves are difficult to eliminate - and any ethylphenols in the mass of the wood are released (Chatonnet et al., 1999). However, some authors (Lonvaud-Funel and Renauf, 2005) report that, due to their higher oxygen and sugar contributions, new barrels are even more likely to favour the maintenance of large Brettanomyces populations. It is probable that the wood pores become blocked as the barrels are used, so the oxygen arriving via them decreases. The frequent re-use of casks and the use of the micro-oxygenation technique to accelerate wine maturation, facilitates the polymerisation of wine pigments and the modification of the wine volatile profile (frequently associated with the use of oak chips or barrel aging), resulting in the proliferation of Brettanomyces/Dekkera (Aguilar-Uscanga et al., 2003; Ciani and Ferraro, 1997; Ciani et al., 2003).

Pollnitz et al. (2000) determined 4-ethylphenol and 4 -ehtylguaiacol concentration in red wine aged in new and used French and American oak barrels of different ages. Wine stored in shaved and renovated with fireing oak barrels contained up to $85 \%$ less 4-ethylphenol and 4-ethylguaiacol than wine stored in usual barrels of the same age that were not shaved. Oak barrels that become contaminated with $B$. bruxellensis cannot be effectively sterilized. Neither careful washing followed by rinsing with sulphited water, nor shaving and firing, nor ozone treatment achieves sterilization (Pollnitz et al., 2000) - a result of the large internal volume and porous nature of oak barrels. The sanitation of barrel wood requires at least $7 \mathrm{~g}$ of $\mathrm{SO}_{2}$ gas per barrel. Filled wine barrels should receive $20-25 \mathrm{mg} \mathrm{l}^{-1}$ of free $\mathrm{SO}_{2}(30-35 \mathrm{mg}$ $1^{-1}$ during hot summers) (Henick-Kling et al., 2000). Malfeito-Ferreira (2005) tested four barrel sanitation procedures: (I) cold water rinse followed 
by three hot water rinses $\left(70{ }^{\circ} \mathrm{C}\right)$; (II) the same as the previous plus filling with an aqueous solution of $\mathrm{SO}_{2}$ (200 mg l-1, pH 3) and storing for one month; (III) cold water rinse, followed by filling the barrel with hot water $\left(90^{\circ} \mathrm{C}\right.$ for $\left.10 \mathrm{~min}\right)$; (IV) cold water rinse, followed by a hot water rinse $\left(70^{\circ} \mathrm{C}\right)$ and low pressure steam $(10 \mathrm{~min})$. The last one appeared the most effective and author recommended isolation of brett infectioned barrels to reduce the contamination of others during disinfection and wine pumping.

Garde-Cerdán et al. (2010) analysed 510 wines, from four different Spanish geographic zones, and aged in different oak barrels types for at least 6, 12 and 18 months. Theyconcluded that accumulation of volatile oak compounds and ethylphenols was affected mainly by the storage time of the wines in the oak barrels, while the oenological parameters, the geographic origin and the oak barrel type had smaller influences on the accumulation of these volatile compounds in the wines. The total average of the ratio 4-ethylphenol and 4-ethylguaiacol of the aged- 6 wines was below that of the aged-12 and aged-18 wines. A ratio for the aged-12 and aged-18 wines was within the range found by Pollnitz et al. (2000), i.e. between 3.5 and 10.1.

However, young red wines in stainless-steel vessels or bottled wines are also prone to this type of spoilage (Rodrigues et al., 2001; Renouf et al., 2007). At the end of barrel aging, before bottling, residual population of $B$. bruxellensis can often be detected (Nisiotou and Gibson, 2005; Renouf et al., 2006; Curtin et al., 2007). Although populations are usually too low at this point to synthesize ethyl-phenols, they could further develop and spoil the wine during bottle storage, when the winemaker can no longer intervene (Coulon et al., 2010).

Recently, results obtained by Rubio et al. (2015) indicated the spoilage risk exists when Brettanomyces cells are present, even at a low level, in wines subjected to aging, both in the cask and the bottle. Brettanomyces presence and ethylphenol production during aging, is affected more by the aging conditions (aerobic/anaerobic and sulphiting) than by the origin of the oak. They had shown that aging only under aerobic conditions with racking and sulphur dioxide addition, showed lower Brettanomyces levels than the combined aerobic and anaerobic maturation with racking but without sulphur dioxide addition. Also, wines aged in Chinese oak revealed different behaviour to the other three in terms of the level of Brettanomyces and in the ethylphenol concentration, probably due to the fact that this oak has the highest porosity.

\section{MEASURES FOR THE PREVENTION}

Prevention of the growth of Brettanomyces/Dekkera in wine involves attention to fruit quality and winery sanitation, control of sulphite and oxygen levels, as well as to the use of uncontaminated barrels (Wedral et al., 2010). B. bruxellensis is found on damaged grapes and in winery equipment, so effective general sanitation is the first step in the prevention. Adequate amounts of $\mathrm{SO}_{2}$ should be added to fermentation vessels and maintained during fermentation in order to inhibit growth of $B$. bruxellensis. After addition of $\mathrm{SO}_{2}$, Brettanomyces enter in to viable but not culturable state, so the yeast may be still present after depletion of free $\mathrm{SO}_{2}$ (Umiker et al., 2007). As control factors, winemakers should consider using a starter yeast culture, alcohol, acid levels, temperature and oxygen exposure. Using a starter culture can decrease indigenous fermentation, decreasing the opportunity for Brettanomyces to grow. Though fermenting wines to a higher alcohol level may often inhibit development of flavour precursors, ethanol tolerance is also a strain dependent character (Vigentini et al., 2008).

Apart from limiting Dekkera growth one way of avoiding ethylphenol production is to minimize the concentration of precursors in wine (Gerbaux et al., 2002). A common oenological technique is the addition of enzyme preparations during maceration to aid in the release of phenolic compounds from the grape berries. These preparations have been shown to be relatively effective in releasing free hydroxycinnamic acids from their esterified form, which then leaves these available for conversion into volatile phenols. Therefore it has been 
recommended that enzyme preparations possessing cinnamoyl esterase not be used in winemaking as it increases the chance of spoilage by volatile phenols (Gerbaux et al., 2002).

Chatonnet et al. (1993) stated that wines are more susceptible to the phenolic taint in warmer months. In fact, the impact of air temperature on 4ethylphenol production was related with the production rate, and not with the total amount produced. Thus, keeping wines at low cellar temperatures only delays the process, being an efficient prevention measure if cell growth is fully inhibited. Couto et al. (2005) already presented lethal heat-treatment parameters for $D$. bruxellensis, showing that significant inactivation of $D$. bruxellensis in wine began at $35{ }^{\circ} \mathrm{C}$, stimulated by the ethanol concentration of wine. In addition, other data (Barata et al., 2008) showed that relatively mild temperatures (about $36{ }^{\circ} \mathrm{C}$ ) overnight are a reasonable technological option when wines are found contaminated by viable $D$. bruxellensis and 4-ethylphenol tends to increase. According to these authors, this mild temperature has no obvious detrimental effects on wine quality and may be achieved using electric devices to heat wine in stainless-steel vessels or simply by heating bottled wine, without disgorging, if contamination could not have been avoided during bottling. Barata et al. (2008) managed to achieve stable levels of 4-ethylphenol $\left(100 \mu \mathrm{g} \mathrm{l}^{-1}\right)$ with viable but non-growing $D$. bruxellensis populations of 2000 CFU $\mathrm{ml}^{-1}$ during barrique storage at low temperatures $\left(6-8{ }^{\circ} \mathrm{C}\right)$. Removal and inactivation of $D$. bruxellensis by strict process operations (e.g. heat treatment, sterile filtration) would only be advisable when there is an increase in the 4ethylphenol levels.

Decreases of 4-ethylphenol and 4-ethylguaiacol concentrations were found in red wine containing yeast lees compared to the same wine aged without lees (Guilloux-Benatier et al., 2001). Chassagne et al. (2005) shown that yeast lees were effective in removal of 4-ethylguaiacol and 4-ethylphenol. Also the presence of other wine constituents sorbed by yeast influenced the sorption of both volatile phenols, with a greater effect in the case of 4-ethylphenol. Yeast lees provide a cost-effective and efficient approach to remove or to decrease organoleptic defects in wine due to phenols.
However, preventive methodologies have been based on the generation of conditions unfavourable to Brettanomyces/Dekkera (Benito et al., 2009). Sturm et al. (2015) also concluded that potential spoilage of wine by $D$. bruxellensis was more related to the ability of the strains to develop in the wine environment than the CD and VR enzymatic activity recorded in laboratory conditions and therefore, the most efficient way to prevent wine spoilage by $D$. bruxellensis should be the control of its development.

Certain additives can inhibit the growth of Brettanomyces (Suarez et al., 2007). The most common is sulphur dioxide $\left(\mathrm{SO}_{2}\right)$, although it is hard to keep the concentration stable over prolonged aging periods in casks in which the environment is mildly oxidizing. It is known that, in a red wine at $\mathrm{pH} 3.65$, initial doses of free $\mathrm{SO}_{2}$ of $15,25,30$ and $35 \mathrm{mg} \mathrm{l}^{-1}$ are significantly reduced after four months of aging in barrels to 6 , 11,10 and $15 \mathrm{mg} \mathrm{l}^{-1}$, respectively (Chatonnet, et al., 1993).

The action of $\mathrm{SO}_{2}$ on Brettanomyces seemed to be rapid, with cells having their viability greatly reduced and losing their culturability completely within $330 \mathrm{~min}$ of exposure. The uptake of free molecular $\mathrm{SO}_{2}$ by Brettanomyces is fast, as exposure of the cells to molecular $\mathrm{SO}_{2}$ for only a short period of time showed (Du Toit et al., 2005). Also, the addition of $\mathrm{O}_{2}$ to wine that contains low concentrations of $\mathrm{SO}_{2}$ can support the survival and growth of Brettanomyces and it usually happen during racking and other transfer or transport. Therefore, when it is suspected that wine has been contaminated by Brettanomyces, it should be avoided excessive $\mathrm{O}_{2}$ exposure and molecular $\mathrm{SO}_{2}$ concentrations should be checked and regularly adjusted to $25-35 \mathrm{mg} \mathrm{l}^{-1}$ of free $\mathrm{SO}_{2}$. Winemakers should bear in mind that at excessive concentrations, $\mathrm{SO}_{2}$ might affect the aroma and colour of red wine because the reaction of $\mathrm{SO}_{2}$ with the red form of anthocyanins leads to the bleaching of red wine colour (Ribéreau-Gayon et al., 2000). The use of between 0.5 and $0.8 \mathrm{mg} \mathrm{l}^{-1}$ of molecular $\mathrm{SO}_{2}$ is recommended and it should be remembered that the molecular $\mathrm{SO}_{2}$ concentration achieved is $\mathrm{pH}$-dependent; $30 \mathrm{mg} \mathrm{l}^{-1}$ of free $\mathrm{SO}_{2}$ releases $0.4 \mathrm{mg} \mathrm{l}^{-1}$ of molecular $\mathrm{SO}_{2}$ at $\mathrm{pH} \mathrm{3.7, \text {and }}$ 0.8 at $\mathrm{pH} 3.4$ (Henick-Kling, et al., 2000). The antimicrobial potential of $\mathrm{SO}_{2}$ against 
Brettanomyces, and the effectiveness of physical treatment like racking to remove yeast cells from barrels have been shown also by (Oelofse et al., 2008; Suárez et al., 2007). Besides, the inhibitory effect of these two actions (sulphating and racking) overcame the stimulating effect of oxygen on Brettanomyces growth (Kheir et al., 2013; AguilarUscanga et al., 2003). Also, lower Brettanomyces levels is achieved when wine is aged only in aerobic conditions (12 months cask) with racking and sulphur dioxide addition, than the combined aerobic and anaerobic maturation (6 months in cask and 6 in bottle) (Rubio et al., 2015).

Filtration can reduce the presence of contaminating yeasts, but this poses problems of reducing wine aroma and colour (Suárez et al., 2007).. In order to be effective, membranes with a pore size smaller than $0.45 \mu \mathrm{m}$ must be used (Calderón et al., 2004) and they causes a deterioration of the wine's colloidal structure and can reduce the intensity of its colour. Dormant, elongated forms of Brettanomyces cells may be able to pass through a $0.45 \mu \mathrm{m}$ filter (Suárez et al., 2007). One of the solutions is fining operation of red wines before introducing them into their barrels and in that way contaminating populations of Brettanomyces can be reduced by 40 to 2000 -fold by treatment with fining proteins (Murat and Dumeau, 2003). There are differences in effectiveness between fining agents and sometimes fining is rejected by winemakers since it also impacts wine aroma and colour. Anyway, the greater reduction in the initial population is achieved when the more fining agents used; i.e. intense finings can almost entirely remove these yeasts (Suárez et al., 2007). Fining with casein or potassium caseinate can reduce ethylphenol levels if these are not too high (RuizHernández, 2003).

It is known that certain weak acids, such as sorbic, benzoic and fumaric have antifungal activity and can be used against Brettanomyces/Dekkera, but their action is not selective and they are not authorized for use in winemaking. Characteristically, weak-acid preservatives do not slay micro-organisms but rather inhibit their growth, causing extended lag phases. Benito et al., (2009) report that sorbic acid can act as inhibitor in conversion of precursor compound to 4ethylphenol but Brettanomyces appear the more resistant yeast species to sorbic acid. Antioxidants such as ascorbic and erythorbic acids can be used to reduce the presence of oxygen during maturation, preventing ethylphenol formation (Suárez et al., 2007).

Other alternative inhibitors are dimethyl dicarbonate and chitosan. Effectiveness of dimethyl dicarbonate has been proven, but Delfini et al. (2002) showed that a dose of $400 \mathrm{mg} \mathrm{l}^{-1}$ cannot completely inhibit the growth of $B$. anomalus and in contrast, other fermentative yeasts are inhibited by dosages of $250-400 \mathrm{mg} \mathrm{l}^{-1}$. Chitosan is a polysaccharide derived from chitin and it has a selective effect on Brettanomyces, causing a delay in its latent phase in mixed cultures with Saccharomyces cerevisiae (Gómez-Rivas et al., 2004). B. bruxellensis and B. intermedius cannot grow in the presence of 3-6 $\mathrm{g} \mathrm{l}^{-1}$ of chitosan, while it does not affect the development of Saccharomyces cerevisiae. Chitosan at 0.05$0.1 \%$ is known to delay spoilage by yeasts at 25 ${ }^{\circ} \mathrm{C}$; in fact it even inactivates some other species (Kiskó et al., 2005).

Puig et al. (2003) showed that application of pressures of 400-500 $\mathrm{MPa}$ for 5-15 min at temperatures of 5 to $20{ }^{\circ} \mathrm{C}$ can reduce populations of certain yeasts (including B. bruxellensis) and lactic acid and acetic acid bacteria by more than $99.99 \%$, without causing major modifications to the wine's physicochemical properties, enzymatic activity, or sensorial properties. Not only is effective, it reduces the use of $\mathrm{SO}_{2}$. The concentration of ethylphenols can be reduced by reverse osmosis and adsorption (Ugarte et al., 2005). These authors reduced initial concentration (900 $\mu \mathrm{l} \mathrm{l}^{-1}$ of 4-ethylphenol plus 4-ethylguiacol) by $77 \%$ after a 3-hours treatment involving reverse osmosis with an appropriate membrane and tangential-flow filtration equipment and a hydrophobic adsorbent resin. Using this method, no significant reduction in wine colour, tannins, body (glycerol and diols) or ethanol was observed, but it was seen reduction in aromatic compounds, like methyl- and ethyl vanillate and other esters (Suarez et al., 2007).

The use of various antimicrobial agents, bacteriolytic enzymes, zymocines and yeast strains with antimicrobial activity constructed by genetic engineering represent biological control of contaminating yeasts and bacteria. However, in the 
wine environment they are not very effective and other techniques are usually required as well $(\mathrm{Du}$ Toit and Pretorius, 2000).

Some wineries use polyvinylpolypyrrolidone and charcoal to treat wines containing volatile phenols. The recommended doses are from 0.015 to $0.24 \mathrm{~g}$ $1^{-1}$ charcoal for slight off-odours, and from 0.12 to $0.96 \mathrm{~g} \mathrm{I}^{-1}$ for more intense off-odours. polyvinylpolypyrrolidone $\left(0.06-0.48 \mathrm{~g} \mathrm{l}^{-1}\right)$ is used to remove ethylphenols (Suarez et al., 2007).

Fulcrand et al. (1996) proposed the formation of the malvidin derivative from 4-vinylphenol in order to decrease the production of ethylphenols and in the same way to increase the formation of highly stable pigments during maturations. Vinyl phenolic derivatives are highly stable due to their aromatic heterocyclic ring. Other pyranoanthocyanic derivatives, such as the vitisins, function in the same way (Mateus, et al., 2001). Besides, since the formation of this ring involves carbon 4 of the anthocyanin, decolouration by $\mathrm{SO}_{2}$ and reductions in colour intensity caused by high $\mathrm{pH}$ are less likely (Bakker and Timberlake, 1997).

Yeasts with hydroxycinnamate decarboxylase activity can also be used to decarboxylate hydroxycinnamic acids, and this forms vinylphenols that condense with grape anthocyanins to produce pyranoanthocyanin vinylphenolic adducts of great colour stability (Morata et al., 2006). This eliminates the hydroxycinnamic acid precursors of ethylphenol from wine, and forms highly stable, long-lasting pyranoanthocyanins during fermentation. During fermentation, vitisins $\mathrm{A}$ and $\mathrm{B}$, pyranoanthocyanic molecules structurally similar to vinylphenol derivatives, are produced in significant amounts by selected yeast strains (Morata et al., 2003). These adduct formed via the condensation of vitisin A and vinylphenols are very stable molecules that provide wine a red-blue colour (Mateus et al., 2006). Benito et al. (2009) used S. cerevisiae strains with high HCDC in order to reduce the concentration of ethylphenol precursors and it is shown that these strains can minimize possible alterations caused by Brettanomyces/Dekkera in red wines. This technique has been proven successful in real musts from the Tempranillo variety and significant differences were obtained in the production of ethylphenols. Such a strategy offers natural protection of this undesirable yeast and volatile phenols concentration below the sensorial threshold can be obtained even after Brettanomyces contamination.

\section{CONCLUSION}

The occurrence of volatile phenols in wines has been extensively studied in last decades and there are a lot of reports on the presence of Brettanomyces metabolites in wine indicating that it is a worldwide issue. Volatile phenols are very important in term of wine sensory characteristics, because their elevated concentrations in wine are associated with unpleasant aroma. As wine market became very demanding and a big wine competition is present, it is very important to place on the market wine that is from sensory points of view in good condition, i.e. without any flaws. As yeast species $B$. bruxellensis is the main culprit for volatile phenols production and if their presence in wine is noticed, the primary objective should be its elimination or its maintenance at constant level. However, winemakers should consider all factors that influence growth of Brettanomyces and volatile phenols production beginning from viticultural practices in order to keep grape healthy, cellar sanitation, physiochemical composition of wine (energy/carbon and precursor sources, alcohol concentration and $\mathrm{pH}$ ) and very important conditions during wine aging and its storage. Using a starter culture is a good preventive measure that can decrease indigenous fermentation, decreasing the opportunity for Brettanomyces to grow. Also, starter cultures can be used to decarboxylate hydroxycinnamic acid precursors of ethylphenol from wine, and forms highly stable, long-lasting pyranoanthocyanins during fermentation i.e. adducts of great colour stability. Generally, from additives the most effective turned out $\mathrm{SO}_{2}$ and its concentration should be orderly checked and maintained on necessary level. Besides, there are differences among grape varieties in hydroxycinnamic acid precursors accumulation and therefore in volatile 
phenols production. Further research that will consider different grapevine varieties, different starter cultures including control of wine in different phases of winemaking process should be put in a word.

\section{REFERENCES}

Agnolucci M., Rea F., Sbrana C., Cristani C., Fracassetti D., Tirelli A., Nuti M. 2010. Sulphurdioxide affects culturability and volatile phenol production by Brettanomyces/Dekkera bruxellensis. International Journal of Food Microbiology, 143(1-2): 76-80. DOI: 10.1016/j.jifoodmicro.2010.07.022

Aguilar Uscanga M. G., Delia M. L., Strehaiano P. 2003. Brettanomyces bruxellensis: effect of oxygen on growth and acetic acid production. Applied Microbiology Biotechnology, 61(2): 157-162. DOI: $10.1007 / \mathrm{s} 00253-002-1197-\mathrm{z}$

Alguilar Uscanga M. G. A., Delia M. L., Stehaiano P. 2000. Nutritional requirements of Brettanomyces bruxellensis: growth and physiology in batch and chemostat cultures. Canadian Journal of Microbiology, 46(11): 1046-1050. DOI: 10.1139/w00-089

Bakker J., Timberlake C. F. 1997. Isolation, identification and characterization of new colorstable anthocyanins occurring in some red wines. Journal of Agricultural and Food Chemistry, 45(1) 35-43. DOI: $10.1021 / \mathrm{j} 960252 \mathrm{c}$

Baumes R., Cordonnier R., Nitz S., Drawert F. 1986. Identification and determination of volatile constituents in wines from different cultivars. Journal of the Science of Food and Agriculture, 37(9): 927-943. DOI: 10.1002/jsfa.2740370915

Barata A., Caldeira J., Botelheiro R., Pagliara D., Malfeito-Ferreira M., Loureiro V. 2008. Survival patterns of Dekkera bruxellensis in wines and inhibitory effect of sulphur dioxide. International Journal of Food Microbiology, 121(2): 201-207. DOI: $10.1016 /$ j.ijfoodmicro.2007.11.020

Benito S., Palomero F., Morata A., Calderón F., SuárezLepe J. A. 2009. Factors affecting the hydroxycinnamate decarboxylase/vinylphenol reductase activity of Dekkera/Brettanomyces: application for Dekkera/Brettanomyces control in red wine making. Journal of Food Science, 74(1): M15-M22. DOI:10.1111/j.17503841.2008.00977.x

Boulton R. B., Singleton, V. L. Bisson L. F., Kunkee R. E. 1996. Principles and Practices of Winemaking. New York, NY: Chapman and Hall,
Buron N., Coton M., Legendre P., Ledauphin J., KientzBouchart V., Guichard H., Barillier D., Coton E. 2012. Implications of Lactobacillus collinoides and Brettanomyces/Dekkera anomala in phenolic offflavour defects of ciders. International Journal of Food Microbiology, 153(1-2): 159-165. DOI:10.1016/j.jifoodmicro.2011.11.002

Calderón F., Morata A., Uthurry C., Suárez J. A. 2004. Aplicaciones de la ultrafiltración en la industria enológica. Últimos avances tecnológicos. Tecnología del vino, 16, 49-54.

Cabrita M.J., Palma V., Patao R., Freitas M.C. 2012. Conversion of hydroxycinnamic acids into volatile phenols in a synthetic medium and in red wine by Dekkera bruxellensis. Food Science and Technology (Campinas), 32(1), 106-111 DOI: 10.1590/s0101-20612012005000024

Carrillo J. D., Tena M. T. 2007. Determination of ethylphenols in wine by in situ derivatisation and headspace solid-phase microextraction - gas chromatography-mass spectrometry. Annals of Bioanalytical Chemistry, 387(7): 2547-2558. DOI: 10.1007/s00216-006-1086-x

Chatonnet P., Boidro J. N. (1988). Dosages de phénols volatils dans les vins par chromatographie en phase gazeuse. Sciences des Aliments, 8: 479-488.

Chatonnet P., Boidron J. N., Pons M. 1990. Maturation of red wines in oak barrels evolution of some volatile compounds and their aromatic impact. Sciences des Aliments, 10: 565-587.

Chatonnet P., Dubourdieu D., Boidron J. N., Pons M. 1992. The origin of ethylphenols in wines. Journal of the Science of Food and Agriculture, 60(2): 165178. DOI: $10.1002 /$ jsfa. 2740600205

Chatonnet P., Dubourdieu D., Boidron J. N., Lavigne V. 1993. Synthesis of volatile phenols by Saccharomyces cerevisiae in wines. Journal of the Science of Food and Agriculture, 62(2): 191-202. DOI: $10.1002 /$ jsfa.2740620213

Chatonnet P., Dubourdieu D., Boidron J. 1995. The influence of Dekkera/Brettanomyces sp. yeast and lactic acid bacteria on the ethylphenol content of red wines. American Journal of Enology and Viticulture, 46: 463-468. 
Chatonnet P., Viala C., Dubourdieu D. 1997. Influence of polyphenol components of red wines on the microbial synthesis of volatile phenols. American Journal of Enology and Viticulture, 48: 463-468.

Chatonnet P., Masneuf I., Gubbiotti M.-C., Dubourdieu D. 1999. Prévention et détection des contaminants par Brettanomyces au coursde la vinification et de l'elevage des vis. Revue Française d'Oenologie, 179: $20-24$

Ciani M., Ferraro L. 1997. Role of oxygen on acetic acid production by Brettanomyces/Dekkera in winemaking. Journal of the Science of Food and Agriculture, 75(4): 489-495. DOI: 10.1002/(sici)1097-0010(199712)75:4<489::aidjsfa902>3.3.co;2-0

Ciani M., Maccarelli F., Fatichenti F. 2003. Growth and fermentation behavior of Brettanomyces/Dekkera yeasts under different conditions of aerobiosis. World Journal of Microbiology and Biotechnology, 19(4): 419-422. DOI: 10.1023/a:1023950803858

Cocolin L., Rantsiou K., Iacumin L., Zironi R., Comi G. 2004. Molecular detection and identification of Brettanomyces/Dekkera bruxellensis and Brettanomyces/Dekkera anomalus in spoiled wines. Applied Environmental Microbiology, 70(3): 13471355. DOI: 10.1128/aem.70.3.1347-1355.2004

Conterno L., Joseph C. M. L., Arvik T. J., Henick-Kling T., Bisson L. 2006. Genetic and physiological characterization of Brettanomyces bruxellensis strains isolated from wine. . American Journal of Enology and Viticulture, 57: 139-157.

Coulon J., Perello M. C., Lonvaud-Funel A., De Revel G., Renouf V. 2009. Brettanomyces bruxellensis evolution and volatile phenols production in red wines during storage in bottles. Journal of Applied Microbiology, doi:10.1111/j.1365-2672.2009.04561.x

Coulter A., Robinson E., Cowey G., Francis I. L., Lattey K., Capone D., Gishen M., Godden P. W. 2004. Dekkera/Brettanomyces yeast - an overview of recent AWRI investigations and some recommendations for its control. In: Bell S., de Garis K., Dundon C., Hamilton R., Partridge S., Wall G. (eds). ASVO Proc. Grapegrowing at the Edge, Managing the Wine Business, Impacts on Wine Flavour, Barossa, Australia: The Australian Society of Viticulture and Oenology, 51-55

Couto J. A., Barbosa A., Hogg T. 2005. A simple cultural method for the presumptive detection of the yeasts Brettanomyces / Dekkera in wines. Letters in Applied Microbiology, 41(6): 505-510. DOI: 10.1111/j.1472-765x.2005.01782.x
Curtin C.D., Bellon J.R., Coulter A., Cowey G., Robinson E., de Barros Lopes M.A., Godden P.W., Henschke P.A., Pretorius I.S. 2005. The six tribes of 'Brett' in Australia - distribution of genetically divergent Dekkera bruxellensis strains across Australian winemaking regions. Aus. Wine Ind. J., 20: $28-36$

Curtin C. D., Bellon J.R., Henschke P.A., Godden P.W., de Barros Lopes M.A. 2007. Genetic diversity of Dekkera bruxellensis yeasts isolated from Australian wineries. FEMS Yeast Res. 7(3): DOI: 471-481. 10.1111/j.1567-1364.2006.00183.x

Deak T., Beuchat L. R. 1996. Handbook of Food Spoilage Yeasts. CRC Press, Inc., Baton, FL. 210 pp.

Degrassi G., Polverino de Laureto P., Bruschi, C.V. 1995. Purification and characterization of ferulate and p-coumarate decarboxylase from Bacillus pumilus. Appl. Environ. Microbiol., 61: 326-332

Delfini C., Gaia P., Schellino R., Strano M., Pagliara A., Ambro S. 2002. Fermentability of grape must after inhibition with dimethyl dicarbonate (DMDC). Journal of Agricultural and Food Chemistry, 50(20): 5605-5611, DOI: 10.1021/jf0256337

Dias L., Dias S., Sancho T., Stender H., Querol A., Malfeito-Ferreira M., Loureiro V., 2003. Identification of yeasts isolated from wine related environments and capable of producing 4ethylphenol. Food Microbiol. 20(5): 567-574, DOI: 10.1016/s0740-0020(02)00152-1

Díez J., Domínguez C., Guillen D.A., Veas R., Barroso C.G. 2004. Optimisation of stir bar sorptive extraction for the analysis of volatile phenols in wines. J. Chromatogr. 1025(2): 263-7

Domínguez, C.; Guillén, D. A.; Barroso, C. G. 2002. Determination of volatile phenols in fino sherry wines. Anal. Chim. Acta 458: 95-102

Dubois P. 1983. Volatile phenols in wines. In: Pigott J. R. (Ed.), Flavour of distilled beverages: origin and development. Chichester: Ellis Horwood: 110-119

Du Toit W. J., Pretorius I. S., Lonvaud-Funel A. 2005. The effect of sulphur dioxide and oxygen on the viability and culturability of a strain of Acetobacter pasteurianus and a strain of Brettanomyces bruxellensis isolated from wine. J. Appl. Microbiol. 98(4): $\quad 862-871, \quad$ DOI: $\quad 10.1111 / \mathrm{j} .1365-$ 2672.2004.02549.x

Edlin D. A. N., Narbad A., Dickinson J. R., Lloyd D. 1995. The biotransformation of simple phenolic compounds by Brettanomyces anomalus, FEMS Microbiol. Lett., 125: 311-316, DOI: 10.1111/j.1574-6968.1995.tb07374.x 
Edlin D. A. N., Narbad A., Gasson M. J., Dickinson J. R., Lloyd D. 1998. Purification and characterization of hydroxycinnamate decarboxylase from Brettanomyces anomalus. Enzyme Microbial Technology, 22(4): 232-239, DOI: 10.1016/s01410229(97)00169-5

Freer S. N. 2002. Acetic acid production by Dekkera/Brettanomyces yeasts. World J. Microbiol. Biotechnol., 18: 271-275

Freer S. N. 1991. Fermentation and aerobic metabolism of cellodextrins by yeasts. Applied and Environmental Microbiology, 57: 655-659

Fugelsang K. C., Edwards G.E. 2007. Wine Microbiology: Practical Applications and Procedures. Second edition. Springer, Berlin.

Fulcrand H., Cameira-dos-Santos P. J., Sarni-Manchado P., Cheynier V., Favre-Bonvin J. 1996. Structure of new anthocyanin derived wine pigments. Journal of the Chemical Society-Perkin Transactions, 1: 735739. DOI: $10.1039 / \mathrm{p} 19960000735$

Ganga M.A., Salinas F., Ravanal C., Garcia V., Carrasco C., Martinez C., Saavedra J. 2011. Cinnamic acid, ethanol and temperatura interaction on coumarate decarboxylase activity and the relative expression of the putative CD gene in $D$. bruxellensis, Electron. J. Biotechnol., 14(15): 3458-3458. DOI: 10.2225/vol14-issue5-fulltext-2

Garde-Cerdán T., Rodriguez Mozaz S., Ancın Azpilicueta C. 2002. Volatile composition of aged wine in used barrels of French oak and of American oak. Food Research International, 35(7): 603-610, DOI: $10.1016 / \mathrm{s} 0963-9969(01) 00151-\mathrm{X}$

Garde-Cerdán T., Lorenzo C., Carot J. M., Esteve M. D., Climent M. D., Salinas M.R. 2010. Effects of composition, storage time, geographic origin and oak type on the accumulation of some volatile oak compounds and ethylphenols in wines. Food Chemistry, 122(4): 1076-1082, DOI: 10.1016/j.foodchem.2010.03.077

Gawel R. 2004. Brettanomyces Character in Wine, Australian Society of Wine Education National Convention Hunter Valley, Australia

Gerbeaux V., Jeudy S., Monamy C. 2000. Study of phenol volatiles in Pinot noir wines in Burgundy. Bulletin de l'OIV, 73: 581-599

Gerós H., Cássio F., Leão C. 2000. Utilization and transport of acetic acid in Dekkera anomala and their implications on the survival of the yeast in acidic environments. J Food Prot.,63: 96-101

Gilliland R. B. 1961. Brettanomyces. I. Occurrence, Characteristics, And Effects On Beer Flavour. Jnl
Institute Brewing, 67: 257-261. doi:10.1002/j.2050-0416.1961.tb01791.x

Godoy L., Martínez C., Carrasco N., Ganga M. A. 2008. Purification and characterization of a p-coumarate decarboxylase and a vinylphenol reductase from Brettanomyces bruxellensis. International Journal of Food Microbiology. 127 (1-2): 6-11, DOI: 10.1016/j.ijfoodmicro.2008.05.011

Goldberg D. M., Tsang E., Karumanchiri A. 1998. Quercetin and p-coumaric acid concentrations in commercial wines. American Journal of Enology and Viticulture, 49: 142-151

Gómez-Rivas L., Escudero-Abarca B. I., AguilarUscanga M. G., Hayward-Jones P. M., Mendoza P., Ramírez M. 2004. Selective antimicrobial action of chitosan against spoilage yeasts in mixed culture fermentations. Journal of Industrial Microbiology and Biotechnology, 31: 16-22

Goody A. R., Tube R. S. 1982. Genetic and biochemical analysis of the ability of $S$. cerevisiae to decarboxylate cinnamic acids. Gen. Microbiol., 128(11): 2615-2620, DOI: 10.1099/00221287-128$11-2615$

Guilloux-Benatier M., Chassagne D., Alexandre H., Charpentier C., Feuillat M. 2001. Influence of yeast autolysis after alcoholic fermentation on the development of Brettanomyces/Dekkera in wine. J. Int. Sci. Vigne Vin, 35: 157-164

Harris V., Ford C. M., Jiranek V., Grbin P. R. 2008. Dekkera and Brettanomyces growth and utilisation of hydroxycinnamic acids in synthetic media. Applied Microbiology and Biotechnology, 78(6):997-1006, DOI: 10.1007/s00253-007-1328-7

Harris V., Ford C. M., Jiranek V., Grbin P. R. 2009. Survey of enzyme activity responsible for phenolic off-flavour production by Dekkera and Brettanomyces yeast. Applied Microbiology and Biotechnology, 81(6): 1117-1127, DOI: 10.1007/s00253-008-1708-7

Henick-Kling T., Egli C., Licker J., Mitrakul C., Acree T. E. 2000. In Proceedings of the 5th international symposium on cool climate viticulture and oenology, Melbourne, Australia, 16-20 January.

Heresztyn T. 1986. Formation of substituted tetrahydropyridines by species of Brettanomyces and Lactobacillus isolated from mousy wines. Am. J. Enol. Vitic., 80: 171-176

Hesford F., Schneider K., Porret N. A., Gafner J. 2004. Identification and analysis of 4-ethyl catechol in wine tainted by Brettanomyces off-flavor. Abstract. Am. J. Enol. Vitic.,55: 304A

Acta agriculturae Slovenica, 107 - 2, september 2016 
Joseph C. M. L., Bisson L. 2004. Physiological diversity of Brettanomyces/Dekkera isolated from wine. In Technical Abstracts, 55 ${ }^{\text {th }}$ Annual Meeting, San Diego, California, American Society for Enology and Viticulture, Davis, CA: p. 28

Kheir J., Salameh D., Strehaiano P., Brandam C., Lteif R. 2013. Impact of volatile phenols and their precursors on wine quality and control measures of Brettanomyces/Dekkera yeasts. European Food Research and Technology, 237(5): 655-671, DOI: 10.1007/s00217-013-2036-4

Kiskó G., Sharp R., Roller S. 2005. Chitosan inactivates spoilage yeasts but enhances survival of Escherichia coli O157:H7 in apple juice. Journal of Applied Microbiology, 98(4): 872-880, DOI: 10.1111/j.1365-2672.2004.02527.x

Kosel J., Čadež N., Raspor P. 2014. Factors affecting volatile phenol production during fermentations with pure and mixed cultures of Dekkera bruxellensis and Saccharomyces cerevisiae. Food Technol. Biotechnol., 52: 35-45

Laforgue R., Lonvaud-Funel A. 2012. Hydroxycinnamic acid decarboxylase activity of Brettanomyces bruxellensis involved in volatile phenol production: relationship with cell viability. Food Microbiol., 32(2): 230-234, DOI: 10.1016/j.fm.2012.06.004

Larue F., Rozes N., Froudiere I., Couty C., Pereira G. P. 1991. Incidence du développement de Dekkera/Brettanomyces dans les mouts et les vins. J. Int. Sci. Vigne Vin, 25: 149-165

Lentz M., Harris C. 2015. Analysis of Growth Inhibition and Metabolism of Hydroxycinnamic Acids by Brewing and Spoilage Strains of Brettanomyces Yeast. Foods, 4(4): 581-593, DOI: 10.3390/foods 4040581

Licker J. L., Acree T. E., Henick-Kling T. 1999. What is 'Brett' (Brettanomyces) flavour? A preliminary investigation. Am. Chem. Soc. Symp., Ser. 714: 96-115

Lonvaud-Funel A., Renauf V. 2005. Incidence microbiologique de l'usage de barriques neuves et/ou de barriques usagées. Revue Française d'Oenologie, 211: 10-14

López R., Aznar M., Cacho J., Ferreira V. 2002. Determination of minor and trace volatile compounds in wine by solid-phase extraction and gas chromatography with mass spectrometric detection. Journal of Chromatography A,966 (1): 167-177

Loureiro V., alfeito-Ferreira M. 2006. Dekkera/Brettanomyces spp. Chapter 13. In:
Blackburn C. de W. (ed). Food spoilage microorganisms. Woodhead Publishing Ltd, Abington, Cambridge, UK: 353-398

Malfeito-Ferreira, M. 2005. Avances recientes en el control de Brettanomyces/Dekkera bruxellensis en vinos. In Enotour Agrovin, Zaragoza, Spain, 28-30 June.

Martorell N., Martí M.P., Mestres M., Busto O., Guasch J. 2002. Determination of 4-ethylguiacol and 4ethylphenol in red wines using headspace-solidphase microextraction-gas chromatography. J. Chromatogr. A 975 (2): 349-354

Mateus N., Silva A. M. S., Vercauteren J., Freitas V. 2001. Occurrence of anthocyanin-derived pigments in red wines. Journal of Agricultural and Food Chemistry, 49: 4836-4840, DOI: $10.1021 / \mathrm{jf001505b}$

Monje M.C., Privat C., Gastine V., Nepveu F, 2002. Determination of ethylphenol compound by headspace solid-phase microextraction in conjuction with gas chromatography and flame ionization detection. Anal. Chim. Acta 458: 111117Morata A., Gómez-Cordovés M. C., Colomo,B., Suárez J. A. 2003. Pyruvic acid and acetaldehyde production by different strains of Saccharomyces cerevisiae: Relationship with vitisin $\mathrm{A}$ and $\mathrm{B}$ formation in red wines. Journal of Agricultural and Food Chemistry, 51: 7402-7409, DOI: 10.1021/jf0304167

Morata A., Gómez-Cordovés M. C., Colomo B., Suárez J. A. 2005. Cell wall anthocyanin adsorption by different Saccharomyces strains during the fermentation of Vitis vinifera L. cv Graciano grapes. European Food Research and Technology, 220: 341-346, DOI: 10.1007/s00217-004-1053-8

Morata, A. Gómez-Cordovés M. C., Suberviola J., Bartolomé B., Colomo B., Suárez J. A. 2003. Adsorption of anthocyanins by yeast cell walls during the fermentation of red wines. Journal of Agricultural and Food Chemistry, 51(14): 40844088. DOI:10.1021/jf021134u

Morel-Salmi C., Souquet J.-M., Bes M., Cheynier V. 2006. Effect of Flash Release Treatment on Phenolic Extraction and Wine Composition. Journal of Agricultural and Food Chemistry, 54(12): 4270-4276. DOI: 10.1021/jf053153k

Murat M.-L., Dumeau F. 2003. Impact of fining on populations levels of certain spoilage microorganisms in red wine. Revue des Oenologues, 107: $16-18$

Nisiotou A. A., Gibson G. R. 2005. Isolation of Culturable Yeasts from Market Wines and 
Evaluation of the 5.8S-ITS rDNA Sequence Analysis for Identification Purposes. Letters in Applied Microbiology, 41(6): 454-463. DOI: 10.1111/j.1472-765x.2005.01795.x

Oelofse A., Pretorius I. S., du Toit M. 2008. Significance of Brettanomyces and Dekkera during winemaking: a synoptic review. S. Afr. J. Enol. Vitic., 29: 128-144.

Oelofse A., Lonvaud-Funel A., du Toit M. 2009. Molecular identification of Brettanomyces bruxellensis strains isolated from red wines and volatile phenol production. Food Microbiology, 26(4): 377-385, DOI: 10.1016/j.fm.2008.10.011

Park S. W., Kim S. W., Hong S. I., Hong Y. K. 1999. Development of strain fermenting the glucose/cellobiose mixed sugar for simultaneous saccharification and fermentation of cellulosic materials. Korean Journal of Applied Microbiology and Biotechnology, 27: 145-152

Park S. W., Kim S. W. 2000. Ethanol production by an immobilized thermotolerant mutant of Brettanomyces custersii H1-39 from wood hydrolyzate media. Korean Journal of Applied Microbiology and Biotechnology, 28: 172-179

Phister T.G., Mills D.A. 2004. Novel methods to detect Brettanomyces (Dekkera) in wine. In Technical Abstracts, 55 ${ }^{\text {th }}$ Annual Meeting, San Diego, California, American Society for Enology and Viticulture, Davis, CA: p. 30

Pollnitz A. P., Pardon K. H., Sefton M. A. 2000. Quantitative analysis of 4-ethylphenol and 4ethylguaiacol in red wine. J. Chromatogr. A, 874: 101-109, DOI: 10.1016/s0021-9673(00)00086-8

Puig A., Vilavella M., Daoudi L., Guamis B., Minguez S. 2003. Microbiological and biochemical stabilization of wines by application of high pressure processing. Bulletin de l'OIV, 76: 596617

Rayne S., Sheppard S., Di Bello T., Eggers N. J. 2008. Chromatic characteristics and optically derived compositional descriptors of micro-oxygenated wines from Vitis vinifera cv. Merlot and Cabernet Sauvignon. Food and Bioprocess Technology. DOI: 10.1007/s11947-008-0152-0

Renouf V., Claisse O., Lonvaud-Funel A. 2007 Inventory and monitoring of wine microbial consortia. Appl. Microbiol. Biotechnol., 75: 149164, DOI: 10.1007/s00253-006-0798-3

Rentzsch M., Schwarz M., Winterhalter P., HermosínGutiérrez I. 2007. Formation of hydroxyphenylpyranoanthocyanins in Grenache wines: Precursor levels and evolution during aging. J. Agric. Food Chem., 55: 4883-4888, DOI: 10.1021/jf0702491

Rodrigues N., Gonçalves G., Pereira-da-Silva S., Malfeito-Ferreira M., Loureiro V. 2001. Development and use of a new medium to detect yeast of the genera Dekkera/Brettanomyces. J. Appl. Microbiol., 90: 588-599, DOI: 10.1046/j.1365-2672.2001.01275.x

Romano A., Perello M. C., de Revel G., Lonvaud-Funel A. 2008. Growth and volatile compound production by Brettanomyces/Dekkera bruxellensis in red wine. J. Appl. Microbiol., 104: 1577-1585, DOI: 10.1111/j.1365-2672.2007.03693.x

Ribéreau-Gayon P. Glories Y., Maujean A., Dubourdieu D. 2000. Handbook of Enology: The Chemistry of Wine Stabilization and Treatments, Vol. 2, 1st ed., Wiley, West Sussex, p. 219.

Ruiz-Hernández M. 2003. Casein for correction of defects caused by Brettanomyces and Dekkera. Semana Vitivinícola, 58: 1462-1463

Salameh D., Brandam C., Medawar W., Lteif R., Sthrehaiano P. 2008. Highlight on the problems generated by $p$-coumaric acid analysis in wine fermentations. Food Chem., 107: 1661-1667, DOI: 10.1016/j.foodchem.2007.09.052

Serpaggi V., Remize F., Recorbet G., Gaudot-Dumas E., Sequeira-Le Grand A., Alexandre H. 2012. Characterization of the "viable but nonculturable" (VBNC) state in the wine spoilage yeast Brettanomyces. Food Microbiol., 30: 438-447, DOI: 10.1016/j.fm.2011.12.020

Chassagne D., Guilloux-Benatier M., Alexandre H., Voilley A. 2005. Sorption of wine volatile phenols by yeast lees. Food Chem., 91: 39-44, DOI: 10.1016/j.foodchem.2004.05.044

Steensels J., Daenen L., Malcorps P., Derdelinckx G., Verachtert H., Verstrepen K. J. 2015. Brettanomyces yeasts - From spoilage organisms to valuable contributors to industrial fermentations, International Journal of Food Microbiology, 206: 24-38, doi: 10.1016/j.ijfoodmicro.2015.04.005.

Silva I., Campos M. F., Hogg T., Couto J. A. 2011. Factors influencing the production of volatile phenols by wine lactic acid bacteria. International Journal of Food Microbiology, 145: 471-475, DOI: 10.1016/j.ijfoodmicro.2011.01.029

Steinke R. D., Paulson M.C. 1964. The production of steam-volatile phenols during the cooking and alcoholic fermentation of grain. J. Agric. Food Chem., 12: 381-387, DOI: 10.1021/jf60134a022

Sturm M. E., Assof M., Fanzone M., Martinez C., Ganga M. A., Jofré V., Ramirez M. L., Combina

Acta agriculturae Slovenica, 107 - 2, september 2016 
M. 2015. Relation between coumarate decarboxylase and vinylphenol reductase activity with regard to the production of volatile phenols by native Dekkera bruxellensis strains under 'winelike' conditions. International Journal of Food Microbiology, 206: 51-5. doi:10.1016/j.ijfoodmicro.2015.04.023.

Suárez R., Suárez-Lepe J.A., Morata A., Calderón F. 2007. The production of ethylphenols in wine by yeasts of the genera Brettanomyces and Dekkera: A review. Food Chem., 102: 10-21, DOI: 10.1016/j.foodchem.2006.03.030

Suezawa Y. 1995. Bioconversions of ferulic acid and $p$ coumaric acid to volatile phenols by halotolerant yeasts, studies of halotolerant yeasts in soy sauce making. Journal of the Agricultural Chemical Society of Japan, 69: 1587-1596, DOI: 10.1271/nogeikagaku1924.69.1587

Toit M., Pretorius I. S. 2000. Microbial spoilage and preservation of wine: using weapons from nature's own arsenal - a review. South African Journal for Enology and Viticulture, 21: 74-92.
Ugarte P., Agosin E., Bordeu E., Villalobos J. I. 2005. Reduction of 4-ethylphenol and 4-ethylguaiacol concentration in red wines using reverse osmosis and adsorption. American Journal of Enology and Viticulture, 56: 30-36

Umiker N. L., Edwards C. G. 2007. Impact of sulfur dioxide on culturability and viability of Brettanomyces in wine. American journal for Enology and Viticulture, 58(3): 417A

Vigentini I., Romano A., Compagno C., Merico A., Molinari F., Tirelli A., Foschino R., Volonterio G., 2008. Physiological and oenological traits of different Dekkera/ Brettanomyces bruxellensis strains under wine-model conditions. FEMS Yeast Res., 8: 1087-1096, DOI: 10.1111/j.15671364.2008.00395.x

Wedral D., Shewfelt R., Frank J. 2010. The challenge of Brettanomyces in wine. LWT Food Sci. Tech., 43: 1474-9, DOI: 10.1016/j.lwt.2010.06.010 